ECOLOGICA, Vol. 28, No 101 (2021), 57-64

https://doi.org/10.18485/ecologica.2021.28.101.10

Originalni naučni rad

UDC:33:502.174.3

316.422.42: 502.174 .3

581.5: 502.174 .3

\title{
Ekonomski, ekološki i društveni aspekti održivog upravljanja obnovljivom energijom
}

\section{Economic, enviromental and social aspects of sustainable renewable energy management}

\author{
Srđan Žikić ${ }^{1}$, Milica Nestorović ${ }^{2}$ Mirjana Stevanović ${ }^{3}$ \\ 1,2Univerzitet Privredna akademija, Fakultet društvenih nauka, Beograd, Srbija \\ 1,2University Business Academy, Faculty of Social Sciences, Belgrade, Serbia \\ ${ }^{3}$ Univerzitet Union - Nikola Tesla, FAM - Fakultet za menadžment, Sremski Karlovci, Srbija \\ ${ }^{3}$ University Union - Nikola Tesla, FAM - Faculty of Management, Sremski Karlovci, Serbia
}

Rad primljen: 24.08.2020, Rad prihvaćen: 15.02.2021.

Sažetak: Sve veći broj naučnih istraživanja ukazuje da izvori obnovljive energije, koji predstavljaju jednu od ključnih komponenti koncepta održivog razvoja, pružaju perspektivu smanjenja ekološke ugroženosti uz istovremeno podsticanje ekonomskog i društvenog razvoja. Na osnovu navedenih činjenica postavljen je osnovni cilj istraživanja, koji predstavlja analiziranje ekološke, ekonomske i društvene prednosti korišćenja energije iz obnovljivih izvora. Rezultati sprovedenog istraživanja nesumnjivo dokazuju da proizvodnja energije iz obnovljivih resursa, pored ekološkog ima naglašen ekonomski i društevni aspekt. Brojne studije navedene u radu dokazuju da se ekološki, ekonomski i društveni aspekti korišćenja obnovljivih izvora energije odnose prvenstveno na korišćenje lokalnih izvora, čime se povećava stepen zaposlenosti, standard života lokalnih zajednica i ravnomerni regionalni razvoj. Obnovljiva energija ima strateški značaj za ukupni društveni razvoj, posebno u onim oblastima u kojima je ekonomski atraktivna zbog svoje dostupnosti. Razvoj energetskog sektora zasnovanog na ekološki čistim obnovljivim izvorima energije, doprinosi poboljšanju kvaliteta života ruralnog stanovništva i modernizaciji poljoprivrede.

Ključne reči: Obnovljiva energija, održivost, održivi razvoj.

\begin{abstract}
An increasing number of scientific research suggests that renewable energy sources, which are one of the key components of the sustainable development concept, provide the prospect of reducing environmental vulnerabilities while encouraging economic and social development. Based on these facts, the main goal of the research is set, which represents the analysis of the ecological, economic and social advantages of using energy from renewable sources. The results of the conducted research undoubtedly prove that the production of energy from renewable resources, in addition to ecological, has an emphasized economic and social aspect. Numerous studies have shown that environmental, economic and social aspects of the use of renewable energy sources relate primarily to the use of local sources, which increases the level of employment, the standard of living of local communities and balanced regional development. Renewable energy has a strategic importance for overall social development, especially in those areas where it is economically attractive due to its availability. The development of an energy sector based on environmentally clean renewable energy sources contributes to improving the quality of life of the rural population and modernizing agriculture.
\end{abstract}

Keywords: Renewable energy, sustainability, sustainable development.

\footnotetext{
${ }^{1}$ orcid.org/ 0000-0003-3982-9433, e-mail: srdjan.zikic@fdn.edu.rs

2orcid.org/0000-0002-8663-1721, e-mail:milica.nestorovic@fdn.edu.rs

${ }^{3}$ orcid.org/0000-0002-3520-1350, e-mail:mira.stev@mts.rs
} 


\section{UVOD / INTRODUCTION}

Istorijski gledano, energija ima izuzetno važnu ulogu u procesu opšteg razvoja i opstanka ljudske civilizacije na planeti. Sve što nas okružuje zasnovano je na korišćenju energije. Nažalost, ubrzani razvoj ljudskog društva tokom poslednja dva veka zasnivao se na prekomernom i nekontrolisanom korišćenju energetskih resursa. Kako se razvijalo moderno društvo, potrebe za energijom su postajale sve veće a rezerve neobnovljivih energetskih resursa koje se u velikom obimu koriste, sve manje. Veliku opasnost predstavlja činjenica da su fosilna goriva, stvarana milijardama godina skoro potrošena u svega nekoliko stotina godina. Za buduće generacije, ostavlja se malo ili nimalo od tog energetskog blaga, ali u nasleđe im zato ostaju zagađenja svih vrsta, sve do onih najstrašnijih - globalnih. Pored toga javljaju se i brojni ekološki problemi - kao što su zagađivanje životne sredine i globalno zagrevanje planete Zemlje. Kao posledica navedenih trendova, koncept održivog razvoja postao je nužna potreba savremenog čovečanstva i vodeća političko - ekonomska paradigma (Lukinović i dr., 2017). Ekonomski sistem koji u dovoljnoj meri ne vrednuje prirodne resurse $\mathrm{i}$ pri tome stimuliše neograničen ekonomski rast, dugoročno je neodrživ (Riznić, 2009).

Kako bi se ovi negativni uticaji eliminisali ili makar umanjili, počelo se sa upotrebom drugih dostupnih izvora energije, tačnije, obnovljivih izvora energije. Tu spadaju praktično energenti sa kojima se svakodnevno susrećemo, kao što su Sunčevo zračenje i snaga vetra, rečni tokovi, biomasa itd. Ovi obnovljivi izvori energije praktično su stalni i sveprisutni, pri čemu ne ugrožavaju životnu sredinu. Međutim, primena svakog od njih ima svoja određena ograničenja, kao što su: relativno visoki finansijski troškovi eksploatacije, globalno nizak nivo svesti pojedinaca o boljim karakteristikama obnovljivih izvora energije u poređenju sa konvencionalnim i sl. (Đukanović, 2008)

Pod pojmom obnovljivi izvori energije, podrazumevaju se izvori energije koji se nalaze u prirodi i obnavljaju se u celosti ili delimično. Obnovljivi izvori energije ili kako se još nazivaju i trajni energetski izvori, predstavljaju energetske resurse koji se koriste za proizvodnju električne energije ili toplotne energije, odnosno svaki koristan rad, čije rezerve se konstantno ili ciklično obnavljaju. Sam naziv obnovljivi, kao i trajni, potiču od činjenice da se energija troši u iznosu koji ne premašuje brzinu kojom se stvaraju u prirodi (Mihajlović-Milanović Z., 2010). Sa jedne strane imamo klasične obnovljive izvore energije, kao što su sagorljivi obnovljivi i otpaci (čvrsta biomasa,drveni ugalj, poljoprivredni i životinjski otpaci, komunalni i industrijski otpaci, biogas) i hidroelektrane; dok s druge strane imamo nove obnovljive izvore, kao što su male hidroelektrane, geotermalna energija, sunčeva energija, vetar, energija mora (talasi, plima i oseka, termalni gradijent).

$\mathrm{Na}$ osnovu navedenih činjenica autori polaze od pretpostavke da primena obnovljivih izvora energije dugoročno posmatrano doprinosi konceptu održivog razvoja, pružajući perspektivu za unapređivanje ekonomskog i društvenog razvoja, uz istovremeno smanjenje ekološke zagađenosti životne sredine. Aktuelizacija sektora obnovljivih izvora energije u nacionalnim ekonomijama,podstiče i ravnomerni regionalni razvoj donoseći nove tržišne mogućnosti. Povezivanje ekonomskih, ekoloških i društvenih faktora predstavlja nesumnjivo osnovu za realizovanje koncepta održivog razvoja. Ovom shvatanju danas pripada centralno mesto u razmatranju dugoročne perspektive opstanka i napretka ekonomija na lokalnom i globalnom nivou (Žikić i dr., 2020).

\section{MATERIJALI I METODE / MATERIALS AND METHODS}

Motiv istraživanja bila je želja da se utvrdi da li postoji opravdanost pretpostavke da primena obnovljivih izvora energije dugoročno posmatrano doprinosi konceptu održivog razvoja, pružajući perspektivu smanjenja ekološke zagađenosti životne sredine uz istovremeno pospešivanje ekonomskog i društvenog razvoja. Osnovni razlog zašto je važno znati odgovor na ovo istraživačko pitanje predstavlja dokazivanje uloge koju održivo upravljanje obnovljivom energijom ima u ekonomskom, društvenom i ekološkom razvoju na globalnom i lokalnom nivou.

Istraživanje je zasnovano na pregledu brojnih studija koje su proučavale prednosti korišćenja obnovljivih izvora energije. Metoda generalizacije, kao osnovna metoda naučnog istraživanja, u radu je poslužila da se na osnovu pojedinačnih saznanja o obnovljivim izvorima energije formiraju opšti stavovi o prednostima njihovog održivog upravljanja. Metoda analize poslužila je za istraživanje pojedinačnih svojstava i međusobne povezanosti efekata korišćenja obnovljivih izvora energije na globalnom i lokalnom nivou. $U$ radu je korišćenja metoda studije slučaja, u okviru koje su razmatrane određene mogućnosti eksploatacije obnovljivih izvora energije u Republici Srbiji. Primeri su odabrani na osnovu njihovog lokalnog značaja i potencijalnih pozitivnih efekata u vidu smanjenja energetske zavisnosti, stvaranju novih radnih mesta i kreiranju vrednosti koje ostaje u lokalnoj ekonomiji. 


\section{REZULTATI I DISKUSIJA /} RESULTS AND DISCUSSION

Ekonomski, društveni i ekološki aspekti i prednosti korišćenja obnovljivih izvora energije odnose se prvenstveno na korišćenje lokalnih izvora, povećavajući na taj način stepen zaposlenosti, prelivanje sredstava ka drugim privrednim granama $i$ povećanje energetske efikasnosti. Masovna primena obnovljivih izvora energije, dugoročno posmatrano, može ojačati nacionalnu ekonomiju, kreirati nova radna mesta i generalno poboljšati kvalitet životne sredine.
Biomasa predstavlja obnovljivi izvor energije koji se dobija iz brojnih izvora, u koje spadaju nusproizvodi drvne industrije i poljoprivrednih useva. Može se koristiti kao zamena za fosilna goriva, u proizvodnji toplotne i električne energije. Za razliku od fosilnih goriva, sagorevanjem biomase se ne povećava količina ugljen-dioksida u atmosferi, što ostvaruje pozitivan uticaj na životnu sredinu. Posmatrajući energetski potencijal biomase u Republici Srbiji, prikazan u tabeli 1 , može se zaključiti da najveću zastupljenost ima poljoprivredna biomasa kao izuzetno veliki potencijal. Takođe, Srbija ima veliki potencijal neiskorišćenih drvnih izvora za energiju.

Tabela 1 - Potencijali biomase u Republici Srbiji

Table 1 - Biomass potentials in the Republic of Serbia

\begin{tabular}{|l|c|c|c|}
\hline & $\begin{array}{c}\text { Iskorišćeni raspoloživi } \\
\text { tehnički potencijal } \\
\text { (milion toe/godišnje) }\end{array}$ & $\begin{array}{c}\text { Neiskorišćeni raspoloživi } \\
\text { tehnički potencijal } \\
\text { (milion toe/godišnje) }\end{array}$ & $\begin{array}{c}\text { Ukupan potencijal } \\
\text { (milion toe/godišnje) }\end{array}$ \\
\hline Biomasa & 1,054 & 2,394 & 3,448 \\
\hline Poljoprivredna biomasa & 0,033 & 1,637 & 1,67 \\
\hline $\begin{array}{l}\text { Delovi poljoprivrednih } \\
\text { vrsta }\end{array}$ & 0,033 & 0,99 & 1,023 \\
\hline $\begin{array}{l}\text { Delovi u voćarstvu, } \\
\text { vinogradarstvu i preradi } \\
\text { voća }\end{array}$ & - & 0,605 & 0,605 \\
\hline Tečno đubrivo & - & 0,042 & 0,042 \\
\hline Drvna (šumska) biomasa & 1,021 & 0,509 & 1,53 \\
\hline Biorazgradivi otpad & - & 0,248 & 0,248 \\
\hline $\begin{array}{l}\text { Biorazgradivi komunalni } \\
\text { otpad }\end{array}$ & - & 0,205 & 0,205 \\
\hline $\begin{array}{l}\text { Biorazgradivi otpad (osim } \\
\text { komunalnog otpada) }\end{array}$ & - & 0,043 & 0,043 \\
\hline
\end{tabular}

Izvor: Ministarstvo rudarstva i energetike, Strategija razvoja energetskog sektora Republike Srbije do 2025. sa projekcijama do 2030

Source: Ministry of Mining and Energy, Energy Sector Development Strategy of the Republic of Serbia for the period 2025 with projections until 2030

Biomasa predstavlja značajan energetski potencijal Republike Srbije. Potencijal biomase procenjuje se na 3,448 miliona toe/godišnje, a u ukupnom potencijalu obnovljive energije učestvuje sa $61 \%$. Najveći deo ovog potencijala predstavlja drvna biomasa (1,53 milion toe/godišnje) i poljoprivredna biomasa (1,67 milion toe/godišnje) zastupljena $u$ ratarstvu, stočarstvu, uzgoju hrane, vinogradarstvu i primarnoj preradi voća. Biorazgradiv otpad (osim komunalnog) uključuje i otpad nastao prilikom proizvodnje ulja za jelo i životinjski otpad (klanički otpad) u ukupnom iznosu od 0,043 miliona toe / godišnje.

Potencijal biomase dostupan je na celoj teritoriji Republike Srbije. Potencijali drvne biomase smešteni su uglavnom na području centralne Srbije a poljoprivredne biomase na području Vojvodine. Pri tome je nivo upotrebe potencijala drvne (šumske) biomase relativno visok $(66,7 \%)$, dok se poljoprivredna biomasa koristi vrlo malo (oko $2 \%$ ). Potencijal biomase, posebno u poljoprivredi, predstavlja dinamičnu kategoriju i da bi se povećao neophodno je preduzeti odgovarajuće aktivnosti za upotrebu i korišćenje neobrađenog i marginalnog zemljišta.

$\mathrm{U}$ tabeli 2 prikazan je potencijal proizvodnje biodizela na površini 350.000 ha, u zavisnosti od sadne strukture uljarica. Teoretski gledano, domaći biodizel može zameniti od $47 \%$ do $55 \%$ ukupne potrošnje fosilnog dizela u sektoru poljoprivrede, odnosno $13 \%$ do $16 \%$ potrošnje u ostalim sektorima. U praksi, ove cifre su manje zbog nemogućnosti organizovanja ekonomske proizvodnje na isparcelisanim poljoprivrednim gazdinstvima. $U$ Srbiji ima dovoljno obradivih površina koje ispunjavaju sve agrotehničke uslove za gajenje uljane repice kao osnovne kulture za proizvodnja biodizela. 
Sa aspekta resursa, ovo bi obezbedilo neophodne uslove da Srbija postane važan evropski proizvođač biodizela. Međutim, za razvoj industrije bio- dizela, neophodno je preduzeti odgovarajuće mere na državnom nivou kako bi se obezbedile preko potrebne investicije u ovaj energetski sektor.

Tabela 2 - Potencijalna proizvodnja biodizela na površini od 350.000 ha u odnosu na setvenu strukturu uljarica

Table 2 - Potential production of biodiesel on an area of 350,000 ha in relation to the sowing structure of oilseeds

\begin{tabular}{|c|c|c|c|c|}
\hline \multirow{2}{*}{ فे } & \multirow{2}{*}{ Struktura setve } & \multirow{2}{*}{$\begin{array}{c}\text { Potencijalna } \\
\text { proizvodnja biodizela } \\
(\mathrm{t})\end{array}$} & \multicolumn{2}{|c|}{$\begin{array}{c}\text { Moguća zamena fosilnog dizela } \\
\text { biodizelom }\end{array}$} \\
\hline & & & Poljoprivreda (\%) & Ostali sektori (\%) \\
\hline $\mathrm{I}$ & $100 \%$ uljana repica & 212.800 & 46,67 & 13,49 \\
\hline II & $\begin{array}{ll}70 \% & \text { uljana repica } \\
30 \% & \text { suncokret } \\
\end{array}$ & 224.140 & 49,16 & 14,21 \\
\hline III & $\begin{array}{l}\text { uljana repica } \\
\text { suncokret }\end{array}$ & 231.700 & 50,81 & 14,69 \\
\hline IV & $\begin{array}{ll}70 \% & \text { uljana repica } \\
30 \% & \text { suncokret }\end{array}$ & 239.260 & 52,47 & 15,16 \\
\hline $\mathrm{V}$ & $100 \%$ suncokret & 250.600 & 54,96 & 15,88 \\
\hline
\end{tabular}

Izvor / Source: Tezić i dr. (2018)

Energetski potencijal geotermalnih resursa Republike Srbije je izuzetno bogat što predstavlja posledicu povoljnog geološkog sastava i povoljnih hidroloških i geotermalnih karakteristika terena. $\mathrm{Na}$ najvećem delu teritorije gustina geotermalnog toplotnog toka je veća od njegove prosečne vrednosti za kontinentalni deo Evrope, koja iznosi oko 60 $\mathrm{mW} / \mathrm{m}^{2}$ Najveće vrednosti od preko $100 \mathrm{~mW} / \mathrm{m}^{2}$ su u Panonskom basenu, centralnom delu južne Srbije i u centralnoj Srbiji. Na teritoriji Srbije van Panonskog basena nalazi se 160 prirodnih izvora geotermalnih voda sa temperaturom većom od $15^{\circ} \mathrm{C}$. Najveću temperaturu od njih imaju vode izvora u Vranjskoj Banji $\left(96^{\circ} \mathrm{C}\right)$, zatim u Jošaničkoj Banji $\left(78^{\circ} \mathrm{C}\right)$, Sijerinskoj Banji $\left(72^{\circ} \mathrm{C}\right)$ itd. Ukupna izdašnost svih prirodnih geotermalnih izvora je oko 4.000 litara u sekundi. Prema sadašnjim saznanjima na teritoriji Srbije postoji 60 nalazišta geotermalnih voda sa temperaturom većom od $15^{\circ} \mathrm{C}$ do dubine od $3000 \mathrm{~m}$.
Ukupna količina toplote koja se nalazi akumulirana u nalazištima geotermalnih voda u Srbiji do dubine od $3 \mathrm{~km}$, oko dva puta je veća od ekvivalentne toplotne energije koja bi se mogla dobiti sagorevanjem svih vrsta ugljeva iz njihovih nalazišta u Srbiji (Radaković, 2010).

Korišćenje geotermalne energije i njenih resursa u Srbiji veoma je malo u odnosu na geotermalni potencijal. Uglavnom se koristi na tradicionalan način, najviše u balneološke i sportsko-rekreativne svrhe. Korišćenje geotermalne energije za grejanje i druge energetske svrhe je u početnoj fazi i veoma skromno $\mathrm{u}$ odnosu na potencijal geotermalnih resursa. $\mathrm{Na}$ prvi pogled razlozi takvog stanja su nerazumljivi, pogotovo kada se uzme u obzir da su pojedini geotermalni lokaliteti među najboljim u Evropi i da je razvoj geotermalne tehnologije u Srbiji, počeo $u$ isto vreme kao i u zemljama u kojima je danas geotermalna tehnologija na najvišem stepenu razvoja.

Tabela 3 - Upotreba hidrogeotermalne energije u Republici Srbiji prema tipu primene

Table 3 - Use of hydrogeothermal energy in Republic of Serbia by type of application

\begin{tabular}{|l|c|c|}
\hline \multicolumn{1}{|c|}{ Vrste primene } & $\begin{array}{c}\text { Instalirana } \\
\text { toplotna snaga MW }\end{array}$ & $\begin{array}{c}\text { Proizvedena } \\
\text { toplota TJ / godišnje }\end{array}$ \\
\hline Grejanje prostora (direktna upotreba) & 18,5 & 575 \\
\hline Balneologija i rekreacija & 36 & 1.150 \\
\hline Sušenje žitarica & 0,7 & 22 \\
\hline Staklenici & 8,4 & 256 \\
\hline Ribolov i stočarstvo & 6,4 & 211 \\
\hline Procesi u industriji & 3,9 & 121 \\
\hline Zagrevanje toplotnim pumpama & 12,0 & 80 \\
\hline Total: & 86,0 & 2.415 \\
\hline
\end{tabular}

Izvor / Source: Jankovic (2009) 
Mali vodotokovi u Srbiji poseduju hidropotencijal koji se može koristi izgradnjom malih hidroelektrana. Procene govore da bi se podizanjem malih hidroelektrana (do $10 \mathrm{MW}$ ) mogao iskoristiti potencijal od 1.600 GWh godišnje, što je ekvivalentno energiji dobijenoj sagorevanjem 400.000 tona nafte. Najveći potencijali se nalaze u slivovima Drine, Lima, Morave i Dunava. Jedno je sigurno, Srbija raspolaže hidroenergetskim potencijalom koji je vredan poštovanja, ali realizacija njegove eksploatacije zavisi od obezbeđivanja uslova za korišćenje.
Male hidroelektrane imaju strateški značaj, kako sa stanovišta sigurnosti snabdevanja lokalnih potrošača električnom energijom proizvedenom iz obnovljivih izvora koji ne ugrožavaju životnu, tako još više sa stanovišta zapošljavanja domaćih kapaciteta za proizvodnju opreme i izvođenje radova. Značajni ekonomski efekti gradnje malih hidroelektrana mogu nastati i zbog relativno velikog domaćeg učešća radne snage i industrije, praktično bez uvoza opreme iz inostranstva.

Tabela 4 - Ukupni energetski efekti malih hidroelektrana u Republici Srbiji Table 4 - Total energy effects of small hydropower plants in Republic of Serbia

\begin{tabular}{|l|c|c|}
\hline \multicolumn{1}{|c|}{ Kategorija malih hidroelektrana } & $\begin{array}{c}\text { Instalirani } \\
\text { kapacitet } \\
\text { (KW) }\end{array}$ & $\begin{array}{c}\text { Proizvodnja } \\
\text { (MWh/godišnje) }\end{array}$ \\
\hline 1. Novi objekti malih hidroelektrana & 442.632 & 1.544 .985 \\
\hline 2. Instalacija hidroelektrana u objektima vodoprivrede & 23.464 & 114.530 \\
\hline - hidroelektrane na izlazu iz biološkog minimuma & 1.064 & 7.500 \\
\hline - hidroelektrane na vodovodnim objektima & 7.000 & 35.000 \\
\hline - hidroelektrane u sistemima za navodnjavanje & 3.000 & 11.000 \\
\hline - hidroelektrane u okviru sistema DTD & 10.400 & 54.030 \\
\hline - hidroelektrane na sistemu prenosa vode iz sliva u sliv & 2.000 & 7.000 \\
\hline 3. Obnova postojećih objekata & 25.769 & 134.000 \\
\hline - obnova postojećih malih hidroelektrana & 8.769 & 54.000 \\
\hline - ugradnja hidroelektrana u mlinove & 10.000 & 45.000 \\
\hline - revitalizacija postojećih hidroelektrana & 7.000 & 35.000 \\
\hline 4. Total & 491.865 & 1.793 .515 \\
\hline
\end{tabular}

Izvor / Source: Jovanovic, Parović (2009)

U protekle dve decenije, obnovljiva energija se razvila od alternativnog izvora energije do jednog od značajnih sila pokretača održive ekonomije 21 . veka. Obnovljivi izvori energije postaju sve bitniji aspekt Evropskog energetskog sistema. Prema Mihajlović-Milanović $Z$. jedino u šta se danas sa dovoljnom sigurnošću može ulagati bez neke bojazni od gubitaka, jesu izvori energije koji se obnavljaju. Istraživanja pokazuju da će se ekonomski, ekološki i energetski najbrže razvijati tehnologije korišćenja hidro potencijala, kao i potencijala vetra, pri čemu će njihovi kapaciteti imati dominatno učešće u strukturi obnovljivih izvora energije (Mihajlović-Milanović Z., 2010). Zabrinutost za sigurnost snabdevanja energijom, ograničenja i fluktuacija cena fosilnih goriva, kao i pretnja klimatskim promenama, ohrabrili su kreatore svetske politike da razmišljaju o strategiji diferzifikacije u snabdevanju energijom i promociji obnovljivih izvora energije. Rezultati studije pokazuju da će obnovljivi izvori energije u SAD-u stvoriti tržište u vrednosti od skoro 10 milijardi $\$$ u 2030. godini (Alireza, Kau-Fui, 2014).
Razvoj proizvodnje energije iz obnovljivih izvora pored brojnih navedenih pozitivnih efekata, dovodi i do dodatnog prelivanje sredstava ka drugim privrednim granama kao što su turizam i poljoprivreda. Ardehali M. u svojoj studiji zaključuje da su ruralna područja zemalja u razvoju mahom nerazvijena i nužno povezana sa poljoprivredom. U većini slučajeva isključivo zavise od sudbine jednog ili dva glavna regionalna preduzeća. Ovo je izuzetno nezavidna situacija pri čemu ove zajednice moraju prvenstveno da obezbede ekonomsku i socijalnu održivost poljoprivrede kroz povećanu eksploataciju obnovljivih izvora energije, koji moraju biti lokalno razvijeni (Ardehali, 2006). Poljoprivredne farme mogu postati konkurentne jedino kroz strategiju smanjenja svojih operativnih energetskih troškova i emisije gasova staklene bašte. Ovo se može postići kroz generisanje energije iz obnovljivih izvora, energetsku efikasnost i smanjenja ukupne potrošnje energije (Carrie et al., 2014).

Veća upotreba obnovljivih izvora energije predstavlja danas prioritet svih nacionalnih ekonomija. Posebno značajnu prednost ovog oblika energije predstavlja mogućnost njenog većeg iskorišćenja, 
odnosno podizanje energetske efikasnosti. Racionalno korišćenje energije putem povećanja energetske efikasnosti zahteva donošenje strateških odluka o uvođenju obnovljivih izvora energije u energetski sektor. Energetska efikasnost ima mnogo šire značenje nego što je tehnološka efikasnost pojedinih procesa i mora obuhvatiti sistem strategija, zakona, propisa, standarda i poreske politike. Prema istraživanju Lotfi i Farhat, Tunis je jedna od retkih zemalja u razvoju koja je razvila proaktivnu politiku promocije obnovljivih izvora energije i energetske efikasnosti već sredinom 1980-ih. Ova politika je dobila poseban zamah počev od sredine 2000-tih, u kontekstu stalnog rasta energetskog deficita. Rezultat ovog ambicioznog programa razvoja obnovljivih izvora energije i energetske efikasnosti predstavlja zadovoljenje energetskih potreba na godišnjem nivou i smanjenje ranjivost ekonomije rastom cena fosilnih goriva (Lotfi, Farhat, 2014). Boroumand u svojoj studiji zaključuje da najvažniji faktori, koji mogu ubediti pojedinca da prilikom eksploatacije energije da prednost obnovljivim izvorima energije u odnosu na konvencionalne, predstavljaju energetska efikasnost, pouzdanost, uslovi održavanja, dostupnost, održivost i uticaj na životnu sredinu. Sektor obnovljive energije je u tom kontekstu pouzdaniji, održiviji, ima manje štetnih uticaja na životnu sredinu i visoku energetsku efikasnost (Boroumand et al., 2012).

Razvoj proizvodnje energije iz obnovljivih izvora dovodi do ukupnog društvenog razvoja doprinoseći poboljšavanju standarda života lokalnih zajednica i ravnomernom regionalnom razvoju. $U$ prilog tome govore dobijeni rezultati velikog broja istraživanja. U studiji koju je sproveo Zervos sa saradnicima napominje se da je zaključno sa 2009. godinom sektor obnovljivih izvora energije obezbedio poboljšanje ukupnog društvenog standarda kreirajući preko 550.000 kvalitetnih radnih mesta, i pri tome imao godišnji obrt koji prevazilazi 70 milijardi evra. Sektor obnovljivih izvora energije ne samo da daje značajan doprinos održivom sistemu snabdevanja energijom i poboljšanju sigurnosti snabdevanja energijom, već podstiče i ravnomerni regionalni razvoj donoseći nove tržišne mogućnosti (Zervos et al., 2010).

Privredni rast i kvalitet životne sredine izgradili su prilično složen međusobni odnos. Zagađenje životne sredine može se objasniti efektom dostignutog nivoa privrednog razvoja, efektom promene strukture privrede i efektom nanete štete životnoj sredini (Cvetanović i dr., 2017). Čovečanstvo je poslednje decenije postalo svesno značaja smanjenja emisije štetnih gasova prilikom sagorevanja fosilnih energenata, kao i problema zadovoljavanja energetskih potreba u bliskoj budućnosti. Pri tome se kao ekološki prihvatljivo rešenje nameću upravo obnovljivi izvori energije. Uključivanje obnovljivih izvora energije u svakodnevni život predstavlja jedan od ključnih faktora sprovođenja koncepta održivog razvoja jer pored očuvanja prirodnih resursa, dovode i do smanjenja emisije štetnih gasova. Krajem 2009. godine sektor obnovljivih izvora energije obezbedio više od $10 \%$ evropske energetske potrošnje. Takođe se navodi da je postignuto smanjenje $7 \%$ emisije gasova staklene bašte $u$ odnosu na nivo iz 1999. godine što je jedna četvrtina od zadatog cilja, a to je $20 \%$ manje emisije gasova staklene bašte $u$ odnosu na nivo iz 1990. godine (Zervos et al., 2010). Zaini A. procenjuje da koncept očuvanja životne sredine predstavlja interdisciplinarni koncept koji istovremeno uzima u obzir prirodne, socijalne $\mathrm{i}$ ekonomske faktore. Ovaj koncept danas predstavlja veliki izazov. Politike vlada mnogih zemalja i njihove naučno-istraživačke strategije usmerene su u pravcu održivog razvoja i zaštite životne sredine, pri čemu obnovljivi izvori igraju veoma važnu ulogu (Zaini, 2012).

U svojoj studiji Von Sperling ističe da je Brazil zemlja u kojoj hidroenergija učestvuje sa čak $70 \%$ u ukupnoj proizvodnji energije, pri čemu je svetski prosek oko $16 \%$. Trenutni instalirani kapaciteti u Brazilu iznose oko $114 \mathrm{GW}$, sa procenjenim ukupnim potencijalom od $260 \mathrm{GW}$. Korišćenje ovog oblika obnovljive energije povezano je sa pozitivnim uticajem na životnu sredinu i privredu, kao što su: poboljšanje kvaliteta same vode u smislu smanjenja zamućenosti i povećanja njene transparentnosti, proizvodnja i snabdevanje regiona jeftinom energijom, kreiranjem novih radnih mesta, kao i supstitucija dizel termoelektrične energije hidroenergijom (Von Sperling, 2012). D. Felten sa saradnicima smatra da energija dobijena iz biomase igra veoma važnu ulogu u globalnoj politici očuvanja životne sredine. Rezultati njihovog istraživanja pokazuju da je emisija $\mathrm{SO}_{2}$ prilikom proizvodnje električne energije iz biomase kukuruza bila manja za $30-76 \%$ u odnosu na proizvodnja energije iz fosilnih goriva, odnosno $29-82 \%$ kada je u pitanju biodizel iz uljane repice. Studija takođe pokazuje da energija biomase pod komercijalnim poljoprivrednim uslovima, može značajno da umanji potrošnju prirodnih resursa (Felten et al., 2013).

U studiji Abdullaha M.A. i saradnika zaključuje se da strategija ublažavanja klimatskih promena može značajno uticati na trenutnu praksu proizvodnje električne energije. Prema ovim autorima povećanje učešća obnovljivih izvora energije u ukupnoj proizvodnji energije predstavlja jednu od ključnih strategija za postizanje ublažavanja efeka- 
ta staklene bašte (Abdullah i dr., 2014). S obzirom na intenzivno usmeravanje fokusa javnosti prema pitanjima klimatskih promena, ocenjuje se da postoji potreba za korišćenjem obnovljive energije iz distributivnih sistema koji su održivi i ekološki čisti. Energetski sistemi zasnovani na korišćenju fosilnih goriva emituju velike količine $\mathrm{SO}_{2}$ u atmosferu, pri čemu doprinose globalnom zagrevanju planete Zemlje i zagađenju životnu sredinu. Ovi autori zaključuju da obnovljivi izvori energije u velikoj meri mogu smanjiti emisuju SO i značajno doprineti rešavanju problema klimatskih promena i globalnog zagrevanja (Shafiullah i dr., 2012). Prema studiji slučaja koju su sproveli Mikael Lantz, i Pål Börjesson biogas proizveden iz stajnjaka i otpada prehrambene industrije može smanjiti emisiju gasova staklene bašte za oko $90 \%$ u poređenju sa konvencionalnim fosilnim gorivima (Lantz, Börjesson, 2014).

\section{ZAKLJUČAK / CONCLUSION}

Rezultati sprovedenog istraživanja nesumnjivo dokazuju da proizvodnja energije iz obnovljivih resursa, pored ekonomskog, ima naglašen društveni i ekološki aspekt. Brojne studije navedene u radu dokazuju da se ekonomski i društveni aspekti korišćenja obnovljivih izvora energije odnose prvenstveno na korišćenje lokalnih izvora, čime se povećava stepen zaposlenosti, standard života lokalnih zajednica i ravnomerni regionalni razvoj. Obnovljiva energija ima strateški značaj za ukupni društveni razvoj, posebno u onim oblastima u kojima je ekonomski atraktivna zbog svoje dostupnosti. Razvoj proizvodnje energije iz obnovljivih izvora pored brojnih navedenih pozitivnih efekata, dovodi i do dodatnog prelivanje sredstava ka drugim privrednim granama kao što su turizam i poljoprivreda. Razvoj energetskog sektora zasnovanog na ekološki čistim obnovljivim izvorima energije, doprinosi poboljšanju života ruralnog stanovništva i modernizaciji poljoprivreda. Ruralna područja zemalja u razvoju, mahom su slabije razvijena i nužno povezana sa poljoprivredom. Neophodno je da ove zajednice obezbede ekonomsku i socijalnu održivost poljoprivrede kroz povećanu eksploataciju obnovljivih izvora energije, koji moraju biti lokalno razvijeni.

Veća upotreba obnovljivih izvora energije predstavlja danas prioritet svih nacionalnih ekonomija. Prednosti korišćenja obnovljivih izvora energije sastoje u tome što se oni zasnivaju na domaćim, lokalnim izvorima i istovremeno utiču na smanjenje uvoza energenata čime podstiču energetsku efikasnost i nezavisnost zemlje. Energija dobijena iz obnovljivih izvora igra veoma važnu ulogu i u globalnoj politici očuvanja životne sredine. Povećanje učešća obnovljivih izvora energije u ukupnoj proizvodnji energije predstavlja jednu od ključnih strategija za postizanje ublažavanja efekata staklene bašte i smanjenju negativnog uticaja sektora energetike na životnu sredinu.

Intenzivnija eksploatacija obnovljivih izvora energije zahteva angažovanje širokog kruga učesnika, kao što su: državne i lokalne uprave, kompanija, građana i organizacija civilnog sektora. Vodeće aktere pri tome predstavljaju vlade država, koje moraju da obezbede uspostavljanje efikasnog institucionalnog i organizacionog okvira, kao i jačanje administartivnih kapaciteta u cilju održivog korišćenja obnovljive energije. Važna uloga države predstavlja i uvođenje podsticajnih mera za proizvođače i korisnike obnovljivih izvora energije, kao i obezbeđenje podrške relevantnim istraživačkim i razvojnim aktivnostima u ovoj oblasti. Državna uprava može u velikoj meri doprineti atraktivnosti obnovljivih izvora na tržištu električne energije i podstaknuti investiranje u ovaj sektor, prventsveno kroz feed-in tarife, poreske olakšice i trgovinom zelenim sertifikatima. Kako su obnovljivi izvori energije važan segment održivog razvoja, koji nije moguće ostvariti bez mobilizacije građana, za širu podršku i primenu obnovljivih izvora energije, neophodno je njihovo što veće učešće. Pri tome građani igraju značajnu ulogu kroz vlastiti izbor većeg korišćenja obnovljivih izvora energije u svojim domaćinstvima, jasnu i izraženu podršku društvenim akterima za promociju obnovljive energije, kao i aktivan angažman unutar ekoloških organizacija civilnog sektora. Javna svest o obnovljivim izvorima može da doprinese socijalnom prihvatanju projekata iz ovog energetskog sektora i sveukupnom poboljšanju energetskog ponašanja potrošača.

\section{LITERATURA / REFERENCES}

[1] Abdullah, M.A., Agalgaonkar, A.P., Muttaq, K.M. (2014). Climate change mitigation with integration of renewable energy resources in the electricity grid of New South Wales, Australia. Renewable Energy, Vol. 66, 305-313.

[2] Alireza, A., Kau-Fui, W. (2014). Analysis of renewable energy development to power generation in the United States. Renewable Energy, Vol. 63, 153-161.

[3] Ardehali, M.M. (2006). Rural energy development in Iran: Non-renewable and renewable resources. Renewable Energy, 31 (5), 655662.

[4] Boroumand Jazi, G., Saidur, R., Rismanchi, B., Mekhilef, S. (2012). A review on the relation between the energy and exergy efficiency analysis and the technical characteristic of the renewable energy systems. Renewable and 
Sustainable Energy Reviews. 16 (5), 3131313.

[5] Carrie, H., Gyamfi, S., Whale, J. (2014). Evaluation of energy efficiency and renewable energy generation opportunities for small scale dairy farms: A case study in Prince Edward Island, Canada. Renewable Energy, 67, 20-29.

[6] Cvetanović, S., Despotović, D., Miličević S. (2017). Privredni rast i zagađenje životne sredine. Ecologica, 24 (86), 225-231.

[7] Đukanović, M. (2008). Životna sredina i održivi razvoj. Beograd: Elit, 32 str.

[8] Energy Sector Development Strategy of the Republic of Serbia for the period by 2025 with projections by 2030, Republic of Serbia, Ministry of Mining and Energy, Belgrade, 2016. pp.14,

[9] Felten, D., Fröba, N., Fries, J., Emmerling, C. (2013). Energy balances and greenhouse gasmitigation potentials of bioenergy cropping systems (Miscanthus, rapeseed, and maize) based on farming conditions in Western Germany. Renewable Energy, Vol. 55, 160-174.

[10] Jankovic, V. (2009). Geothermal energy: How to use the hidden potential of Serbia. Jefferson institute.

[11] Jovanovic, B., Parović, M. (2009). Status and development of small hydropower plants in Serbia. Jefferson institute.

[12] Lantz, M., Börjesson, P. (2014). Greenhouse gas and energy assessment of the biogas from co-digestion injected into the natural gas grid: A Swedish case-study including effects on soil properties. Renewable Energy, Vol. 71, 387-395.

[13] Lotfi S., Farhat F. (2014). Experiences in renewable energy and energy efficiency in Tunisia: Case study of a developing country. Renewable and Sustainable Energy Reviews. Vol. 32, 729-738.
[14] Lukinović, M., Jovanović, Đ., Jovanović, L. (2017). Održivi razvoj i ekosistemska odgovornost kroz uvođenje etičkih principa u savremenom poslovanju. Ecologica, 24 (86), 241247.

[15] Mihajlović-Milanović, Z. (2010). Obnovljivi izvori energije. Beograd, Univerzitet Megatrend, 76 str.

[16] Radaković, M. (2010). Obnovljivi izvori energije i njihova ekonomska ocena. AGM knjiga, 35 str.

[17] Riznić, D. (2009). Globalizacija i promene u ekonomiji i njihov uticaj na životnu sredinu. Ecologica, 16 (55), 484-488.

[18] Shafiullah, G.M., Amanullah, M.T.O., Shawkat Ali, A.B.M., Jarvis, D., Wolfs.P. (2012). Prospects of renewable energy - a feasibility study in the Australian context. Renewable Energy, 39 (1), 183-197.

[19] Terzić I., Šušteršič, V., Nešović, A., Josijević, M. (2018). Possibilities for the use of biofuels in Europa and in Serbia. Mobility \& Vehicle Mechanics, pp. 55.

[20] Von Sperling, E. (2012). Hydropower in Brazil: Overview of Positive and Negative Environmental Aspects. Energy Procedia, Vol. 18, pp. 110-118, 2012

[21] Zervos et al. (2010). RE-thinking 2050. Brussels, European Renewable Energy Council, Renewable Energy House.

[22] Ziani, A. (2012). Renewable Energy, Sustainable Development and Environmental Protection in Ksours (Case of Algeria). Energy Procedia, Vol. 18, 666-671.

[23] Žikić, S., Trifunović, D., Ranđelović, M. (2020). Zadovoljstvo poslom u funkciji održivog menadžmenta hotelskog sektora Stare planine. Ecologica, 27 (99), 530-537. 